\title{
Environmental Toxicity of Sodium Fluoride on Fertility in Male Rats and the Protective Role of Inulin Extract
}

\author{
Amoura M. Abou-EI Naga ${ }^{1}$, Mahmoud S. Ibrahim ${ }^{2}$, Maie I. EI Gammal*2, Omnya A.EI-Batrawy ${ }^{2}$, \\ Mona A. $\mathrm{Abbas}^{3}$ \\ 1Zoology Department, Faculty of Science, Mansoura University, Egypt \\ ${ }^{2}$ Environmental Sciences Department, Faculty of Science, Damietta University, Egypt. \\ ${ }^{3}$ Environmental Sciences Department, the Libyan Academy, Benghazi, Libya.
}

Received: 10 October 2017 /Accepted: 2 December 2017

*Corresponding author: El-Gammal@yahoo.com

\begin{abstract}
The aim of this work to investigate the effects of sodium fluoride $(\mathrm{NaF})$ on male reproductive function and evaluate the protective effects of inulin against sodium fluoride $(\mathrm{NaF})$ induced male reproductive toxicity in adult male albino rats.

In this study, forty adult male albino rats were used, they were divided randomly into four groups: a control group (1), which was given distilled water, and three treatment groups, which was received daily oral doses of; sodium fluoride (10 mg/kg.b.w.) of group (2), inulin (10 mg/kg) + sodium fluoride (10 mg/kg) of group (3), and inulin (10 mg/kg.b.w.) of group (4) for 3 months.

The sperm quality, complete sperm motility, morphology and sperm count were assessed. The levels of follicle-stimulating hormone (FSH), luteinizing hormone (LH), estradiol (E2), testosterone $(\mathrm{T})$, and progesterone $(\mathrm{P})$ were used as indicators of male reproductive health. The whole testis tissues isolated was used for histopathological studies.

The results showed that sodium fluoride induces severe toxic changes in the male reproductive system and inulin could provide these toxic effects.
\end{abstract}

Keywords: sperm quality, Sodium Fluoride, Inulin testosterone, picture of the blood.

\section{Introduction}

Fluoride is an essential element to human body; naturally exists in water, soil, and food. Human are exposed to fluoride from a number of sources, including drinking water, dental products and other commodities (Long et al., 2009; Edzwald, 2011). Human are exposed to fluoride from a number of sources, including drinking water, dental products. Fluoride is a ubiquitous element in the environment, as a widespread natural pollutant, fluoride normally enters human body through drinking water, food, industrial pollution, drugs, cosmetics (Zhanga $\boldsymbol{e t}$ al., 2013).

The increasing exposure to environmental pollutants and chemicals contributes as a major cause for reproductive health problems. Approximately $15 \%$ of human couples are affected by infertility, and about half of them can be attributed to men that the quality of human sperm is decreasing because of environmental pollutants and chemicals (OrtizPerez et al., 2003; Spittle, 2009). Literature 
search revealed that fluoride was shown to decrease fertility and negatively affects sperm function, including morphology, motility, capacitation, and the acrosome reaction $(\operatorname{Kim} e t$ al., 2015).

Epidemiological investigations have established a statistically significant relationship between excessive fluoride exposure to male infertility and low birth rates (Freni, 1994; Long et al., 2009). Furthermore, animal experimental evidence the deleterious impact of fluoride on sperm morphology and motility, capacitation, hyper activation, and spermatogenesis (Sun et al., 2010; Zhu et al., 2014). Additionally, numerous clinical investigations and animal studies revealed that fluoride is a testicular toxicant that disrupts reproductive hormones levels, induces structural and functional defects in sperm and consequently reduced fertility ( $\mathbf{L u}$ et al., 2014; Sun et al., 2014; Dong et al., 2016).

Epidemiological studies indicated that environmental exposure to fluoride was associated with male and low birth rates in endemic areas of fluorosis. The potential relationship between long-term fluoride exposure and fertility impairment has attracted concern (Long et al., 2009; Spittle, 2009). The importance of reproductive health on offspring development has also prompted an epidemiological investigation into the apparent connections between excessive fluoride exposure and male infertility and low birth rates (Freni, 1994; Ortiz-Perez et al., 2003).

Inulin is a water-soluble storage polysaccharide and belongs to a group of nondigestible carbohydrates called fructose. Inulin is extensively available in about 36,000 species of plants, amongst, chicory roots are considered as the richest source of inulin. Commonly, inulin has been a part of our daily food intake for centuries contributing to nutritional properties and exhibits significant technological benefits (Shoaib et al., 2016).

Although, the role of inulin has also been explored in the past few years but nutritional and health benefits along with food applications, specifically its use as functional food was focused in this review. Therefore, the goal of this study was to investigate the effects of sodium fluoride $(\mathrm{NaF})$ on male reproductive function. The protective effects of inulin was evaluated against sodium fluoride $(\mathrm{NaF})$ induced male reproductive toxicity in adult male albino rats.

\section{Experimental Methodology}

The present study investigated the environmental toxicity of sodium fluoride (NaF) on fertility in male rats. The sperm quality, complete sperm motility, morphology and sperm count, sperm abnormality were assessed. The levels of follicle-stimulating hormone (FSH), luteinizing hormone $(\mathrm{LH})$, estradiol $\left(\mathrm{E}_{2}\right)$, testosterone $(\mathrm{T})$, and progesterone $(\mathrm{P})$ were used as indicators of male reproductive health.

\section{Experimental Protocol}

Forty adult male albino rats were used in this study, 250-350 $\mathrm{g}$ in weight along with the supplies of their standard diet and maintained in controlled conditions at $24 \pm 22 \mathrm{C}$, and $12 \mathrm{hr}$. light/12 hr. dark cycle. All animals were housed in stainless-steel cages suspended in stainlesssteel racks for 90 days with relative humidity ranging from $30 \%$ to $55 \%$. Briefly, the albino rats were divided randomly into four groups of 40 each: a control group (1), which was given distilled water, and other three treatment groups, which was received daily oral doses of; sodium fluoride (10 mg/kg.b.w.) of group (2), inulin $(10 \mathrm{mg} / \mathrm{kg})+$ sodium fluoride $(10 \mathrm{mg} / \mathrm{kg})$ of group (3), and inulin (10 mg/kg.b.w.) of group (4) for 3 months (Table 1).

Table (1): Demographic Characteristics of Controls and Treated Animals.

\begin{tabular}{|c|c|c|c|c|c|}
\hline Groups & No & $\operatorname{sex}$ & $\begin{array}{c}\text { Body } \\
\text { weight } \\
\text { gain (g) }\end{array}$ & Dose & Treatment \\
\hline Group 1 & 10 & $\delta$ & $\begin{array}{l}255.32 \pm \\
29.22\end{array}$ & \begin{tabular}{|l}
--- \\
\end{tabular} & Control \\
\hline Group 2 & 10 & $\hat{\sigma}$ & $\begin{array}{l}263.08 \pm \\
16.46\end{array}$ & $10 \mathrm{mg} / \mathrm{kg} . \mathrm{b} . \mathrm{w}$ & $\begin{array}{l}\text { Sodium } \\
\text { fluoride (Naf) }\end{array}$ \\
\hline Group 3 & 10 & d & $\begin{array}{l}252.50 \pm \\
41.31\end{array}$ & $\begin{array}{l}10 \mathrm{mg} / \mathrm{kg} . \mathrm{b} . \mathrm{w} \text { Naf. } \\
+10 \mathrm{mg} / \mathrm{kg} . \mathrm{b} . \mathrm{w} \\
\text { Inuli }\end{array}$ & $\begin{array}{l}\text { Sodium } \\
\text { fluoride + } \\
\text { Inulin }\end{array}$ \\
\hline Group 4 & 10 & $\widehat{\sigma}$ & $\begin{array}{l}269.75 \pm \\
29.37\end{array}$ & 10 mg/kg.b.w & Inulin \\
\hline
\end{tabular}

The whole testis tissues isolated was homogenized in cold saline solution and the homogenate was kept frozen at $-20^{\circ} \mathrm{C}$ until being analyzed, weighed and the testis were stored in $10 \%$ buffer formalin and later used for histopathological studies .

\section{Semen Analysis}

Semen analysis was done for each animal in the studied groups. These include sperm count/ million, abnormalities, Sperm vitality and sperm 
quality Each semen specimen was taken by cutting tail portion of epididymis of male rats liberating sperm in $1 \mathrm{ml}$ of phosphate buffered saline solution for at least half an hour.

\section{Serum Sampling and Detection of Hormones Levels}

After the administration of $\mathrm{NaF}$ for 90 days, the rats were sacrificed. Blood were then collected from the hearts and placed in a refrigerator for about $2 \mathrm{hr}$. Serum was stored at $20^{\circ} \mathrm{C}$ until analysis. The serum hormone levels of FSH, LH, E2, TH and PH were measured using radioimmunoassay kits and automated analyzer.

\section{Statistical Analysis}

Results were expressed as means \pm SE. Statistical significance was calculated using oneway analysis of variance (ANOVA). All the statistical analysis was carried out with the use of SPSS 22 software. Differences were considered Significant at $\mathrm{P} \leq 0.05$.

\section{Results and Discussion}

\section{Semen Quality}

Table 2 indicates the results at the survival periods of 90 days after the administration of sodium fluoride $(\mathrm{NaF})$ and inulin for treated male albino rats. The sperm count of $(6.05 \times 106 / \mathrm{ml})$ when compared to that of control group in male rats $(23.21 \pm 5.56$ $\times 106 / \mathrm{ml})$, and decreased in group $3(16.82 \pm 6.13$ $\times 106 / \mathrm{ml}$ ) compared to the controls. Whereas, it was decreased weak in the sperm count of group
4 (inulin) $(20.82- \pm 9.87 \times 106 / \mathrm{ml})$ compared to the controls.

The sperm motility of group $2(\mathrm{NaF})$ had decrement significantly to $(26 \%)$ when compared to that of (non-treated) control group of male rats $(72.86 \%)$, and decreased in group3 (43\%) compared to the controls. Whereas, weak decreased in the sperm count of group 4 $(64.80 \%)$ compared to the control. The sperm motility of group 2 had decrement significantly (38.4) when compared to that of control group (90), and decreased in group 3 (85) compared to the controls. Whereas, there was weak decreased in the sperm count of group 4 (88) compared to the controls. That indicated that fluoride exposure caused a decrease in spermatozoa, these results are in agreement with Izquierdo-Vega et $\boldsymbol{a l}$. (2008).

Fluoride exposure affects the spermatozoa motility, motility was significantly reduced in spermatozoa from fluoride treated rats, compared with the control group $(81 \pm 6.8 \mathrm{vs}$. $92 \pm 5.6, p=0.027)$, respectively. The spermatozoa concentrations were $(106$ cells $/ \mathrm{ml})(97 \pm 0.95$ vs. 41.1 $\pm 14.2, \quad \mathrm{p}=0.027)$, respectively and the spermatozoa. Viability was $(95 \pm 1.5,30.6 \pm 13.5)$, respectively. These results are in agreement with Sun et al. (2016) that fluoride lowered sperm motility mainly by damaging mitochondrial respiration rather than glycolysis. Similar observation was investigators by Lu et al. (2014) that $\mathrm{NaF}$ affects the mice sperm chemo-toxic function and decrease the number of sperms. In contrast, Eraslan et al. (2007) demonstrated there were no effects of $\mathrm{NaF}$ exposure on the sperm number and morphology as well as body weight and organ absolute and relative weights, in spite of the presence of a mild degree of dental fluorosis in the higher dose.

Table (2): Effect of NaF, on Sperm Count, Motility and Viable of Male Albino Rats Comparing to the Protective Effects of Inulin against Sodium Fluoride $(\mathrm{NaF})$ as well as Controls.

\begin{tabular}{c|c|c|c|c|c}
\hline \multirow{3}{*}{ Parameters } & & \multicolumn{4}{|c}{ Groups } \\
\cline { 3 - 6 } & & $\begin{array}{c}\text { Control } \\
\text { Group (1) }\end{array}$ & $\begin{array}{c}\text { Sodium fluoride } \\
\text { group (2) }\end{array}$ & $\begin{array}{c}\text { Sodium fluoride and } \\
\text { Inulin group (3) }\end{array}$ & $\begin{array}{c}\text { Inulin } \\
\text { group(4) }\end{array}$ \\
\hline \multirow{3}{*}{$\begin{array}{c}\text { Count } \\
\mathbf{1 0} / \mathbf{m l}\end{array}$} & Mean \pm SD & $23.21 \pm 5.56$ & $6.05 \pm 1.48$ & $16.82 \pm 6.13$ & $20.82 \pm 9.87$ \\
\cline { 2 - 6 } & Pvalue & --- & 0.01 & 0.47 & 0.95 \\
\cline { 2 - 6 } & \%ofchange & --- & -73.93 & -27.53 & -0.44 \\
\hline \multirow{3}{*}{\begin{tabular}{c} 
Motility\% \\
\cline { 2 - 6 }
\end{tabular}} & Mean \pm SD & $72.86 \pm 25.7$ & $26 \pm 20.73$ & $43 \pm 32.71$ & $64.80 \pm 29.2$ \\
\cline { 2 - 6 } & Pvalue & ---- & 0.04 & -40.426 & 0.974 \\
\hline \multirow{2}{*}{$\begin{array}{c}\text { Viable/ } \\
\text { Dead }\end{array}$} & Mean \pm SD & $90 \pm 5.19$ & $38.4 \pm 31.67$ & $85 \pm 5.00$ & $88 \pm 6.64$ \\
\cline { 2 - 6 } & P value & ----- & 0.002 & 0.644 & 0.912 \\
\cline { 2 - 6 } & of \% change & ---- & -57.33 & -5.55 & -2.22 \\
\hline
\end{tabular}

$\mathrm{P}<0.05$. $(\mathrm{n}=5)$.* Significant at $\mathrm{P}<0.05$ Abbreviations; $\mathrm{C}$, Control; NaF; sodium fluoride, NaFI; sodium fluoride and Inulin, I; Inulin 
Results from previous studies indicated a statistically significant relationship between excessive $\mathrm{F}$ exposure to male infertility and low birth rates (Freni, 1994; Long et al., 2009), which is supported by our previous study that high $\mathrm{F}$ administration induced poor mice reproductive outcomes (Sun et al., 2011).

\section{Analysis According to Count and Motility of Sperms}

The application of cluster analysis based on the similarity different count and motility values of sperms of different control and treated groups (4 variables) led to the recognition of three groups. The high similarity index in parameters values between each type appears within the same group, while differential index parameter values separate them in different groups (A, B and C).

Group A comprises two groups; control and inulin treated group. Group B comprises one site; NaF-Inulin treated group. Group C comprises one site; $\mathrm{NaF}$ treated group. From the results, control and Inulin treated group drains showed high similarity in the different count and motility values of sperms Figure (1).

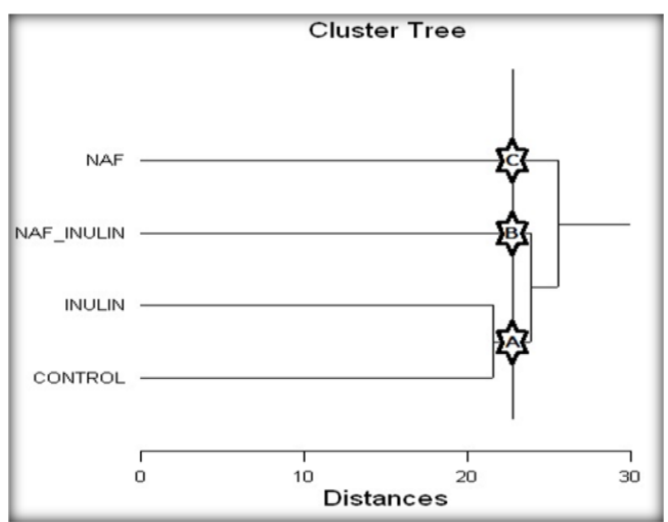

Fig. (1): Analysis of different rat groups according to count and motility of sperms of treated and control rats.

Sperm Counts: The changes in the Sperm Count in the different treated groups. High sperm count about as over 23.2-20 X10\% $/ \mathrm{ml}$ semen in (A-B), moderate sperm count about $16.82 \times 10^{6} / \mathrm{ml}$ semen IN (D) and low sperm count about $6.05 \times 10^{6} / \mathrm{ml}$ semen IN (C)(100X).

\section{Evaluation Hormones Level in Treated Rats and Controls}

Table 3 represents the comparison between the treated group with Sodium fluoride comparing to the protective effects of inulin against sodium fluoride $(\mathrm{NaF})$ as well as controls.

It was established that there was a significant decrease in the concentration of the testosterone, luteinizing hormone $\mathrm{LH}$ and follicle stimulating hormone (FSH) in comparing with controls. These results are in accordance with previous research with rats where showed fluorosisation marked reduction in testosterone hormone (Susheela and Jethanandani, 1996; Huang et al., 2007). Confirmatory results derived by Reddy et al. (2007), where serum testosterone follicle stimulating hormone and luteinizing hormone, were significantly altered in rats after exposure to $\mathrm{Na} \mathrm{F}$. In addition, testicular disorders have been reported to be associated with Na-F-induced oxidative stress in reproductive organs along with possible adverse effects of fluoride on pituitary testicular axis. Similar findings were reported by (Ghosh $\boldsymbol{e t}$ al., 2002; Wan et al., 2006; Han et al., 2015; Li et al., 2016).

However, progesterone and estradiol $\left(\mathrm{E}_{2}\right)$ levels showed a significant increase in comparing with controls. Whereas, the decline in serum hormone established in the protective effects of inulin against sodium fluoride $(\mathrm{NaF})$ induced male reproductive toxicity of adult male albino rats. However, the reduction in the testosterone level is correlated with the testicular spermatogenic day's dysfunction were also found in a study of Chandra et al. (2007). 


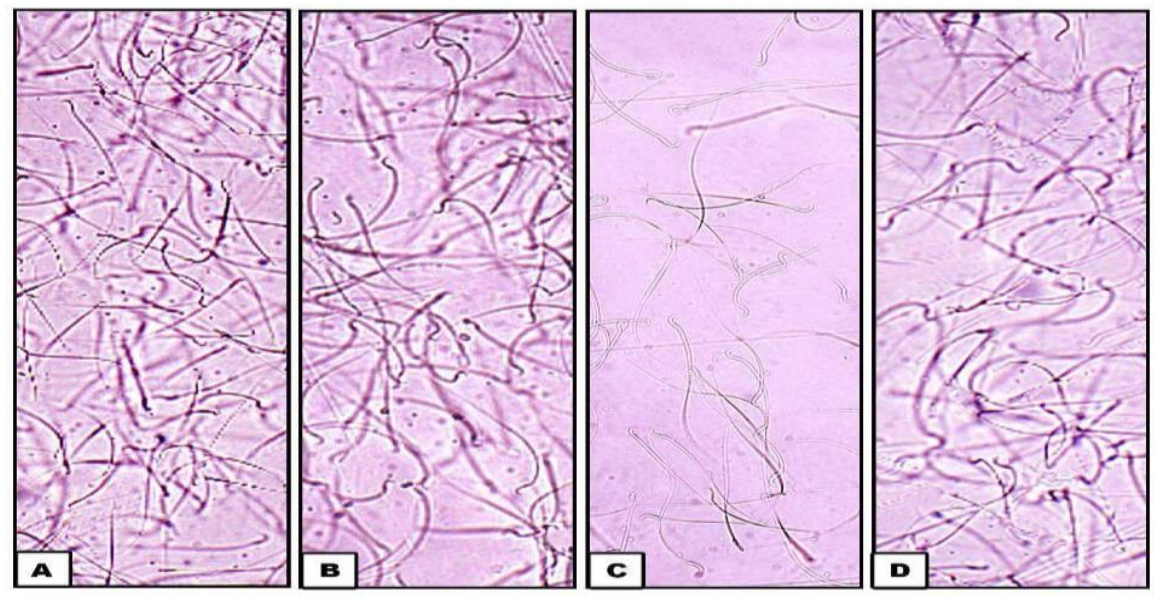

Fig. (2): Photomicrograph of semen represents three different sperm count throughout the different experimental groups showing the numerical sperm values.

Abbreviations: ( A). Control group,(B) Inulin group,(C) sodium fluoride group ,(D) sodium fluoride and inulin group.

Table (3): Effect of NaF, on serum (LH, TESTO, FSH, E2, PGH) of Male Albino Rats received daily oral dose of sodium fluoride $(\mathrm{NaF})$ and inulin comparing to Controls

\begin{tabular}{|c|c|c|c|c|c|}
\hline \multirow[b]{2}{*}{ Parameters } & & \multicolumn{4}{|c|}{ Groups } \\
\hline & & $\begin{array}{l}\text { Control } \\
\text { group }\end{array}$ & $\begin{array}{c}\text { Sodium fluoride } \\
\text { group }\end{array}$ & $\begin{array}{l}\text { Sodium fluoride } \\
\text { and Inulin group }\end{array}$ & Inulin group \\
\hline \multirow{3}{*}{$\begin{array}{c}\text { LH } \\
(\mathbf{M U} / \mathbf{m l})\end{array}$} & Mane \pm SD & $0.013 \pm 0.009$ & $0.010 \pm 0.011$ & $0.0125 \pm 0.009$ & $0.0125 \pm 0.009$ \\
\hline & $P$ value & ---- & 0.732 & 1.000 & 1.00 \\
\hline & Of \%change & ---- & -23.07 & -3.85 & -3.85 \\
\hline \multirow{3}{*}{$\begin{array}{l}\text { TESTO } \\
(\mathrm{pg} / \mathrm{ml})\end{array}$} & Mane \pm SD & $630.22 \pm 118.11$ & $177.03 \pm 36.84$ & $117.52 \pm 8.59$ & $585.05 \pm 172.78$ \\
\hline & P value & ----- & 0.00 & 0.00 & 0.56 \\
\hline & Of \% change & 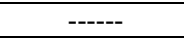 & -71.91 & -81.35 & -7.17 \\
\hline \multirow{3}{*}{ FSH (MU/ml) } & Mane \pm SD & $0.12 \pm 0.08$ & $0.11 \pm 0.02$ & $0.08 \pm 0.05$ & $0.09 \pm 0.02$ \\
\hline & P value & ---- & 0.738 & 0.242 & 0.550 \\
\hline & Of \% change & ----- & -8.33 & -33.33 & -25 \\
\hline \multirow{3}{*}{$\begin{array}{c}\mathbf{E}_{2} \\
(\mathbf{n g} / \mathbf{L})\end{array}$} & Mane \pm SD & $14.86 \pm 2.48$ & $24.07 \pm 4.57$ & $21.22 \pm 6.00$ & $19.82 \pm 6.20$ \\
\hline & $P$ value & ----- & 0.024 & 0.099 & 0.189 \\
\hline & Of \% change & ----- & +61.98 & +42.8 & +33.4 \\
\hline \multirow{3}{*}{$\begin{array}{l}\text { PGN } \\
(\text { ng/ml) }\end{array}$} & Mane \pm SD & $1.03 \pm 0.04$ & $0.80 \pm 0.19$ & $0.76 \pm 0.17$ & $1.04 \pm 0.12$ \\
\hline & P value & ----- & 0.044 & 0.021 & 0.885 \\
\hline & Of \% change & ------ & -22.33 & -26.21 & +0.97 \\
\hline
\end{tabular}

Each value represented the mean $\pm \mathrm{SD} . \mathrm{P}<0.05$. $(\mathrm{n}=5)$.* Significant at $\mathrm{P}<0.05$

Note: The levels of LH (reference range $=1.7-8.6 \mathrm{IU} / 1$ ), FSH (reference range $=1.5-12.5 \mathrm{IU} / 1$ ), and testosterone (reference range $=2.5-8.0 \mathrm{ng} / \mathrm{l}$ ) immunometric assay using commercial kits and automated analyzer

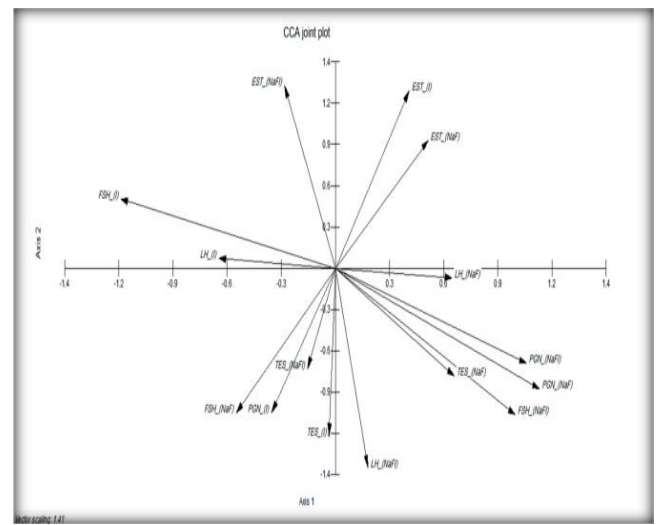

Fig. (3): Canonical Corresponding Analysis (CCA) ordination diagram of serum hormones of male tested rats (arrows) according to the gradient of the same variables of control sample.

\section{Histopathological Examination}

In this prospective study, we observed the testis of control and inulin groups, show normal morphological appearance of seminiferous tubules in various shapes and sizes with stratified epithelium. Each tubule showed regular arrangement of the spermatogenic cells (spermatogonia, spermatocytes and spermatids).

Spermatogonia and Sertoli cells rested on the basement membrane, surrounded by a concentric my fibroblast layer. Many metamorphosed spermatids and spermatozoa were observed near the lumen of the tubules. Leydig cells were situated in between the tubules. 
Sertoli cells were present in all somniferous tubules (Figs. A, B).

After 90 days of sodium fluoride treatment, the testes showed degenerative changes and arrest of spermatogenesis. Also showing, decreases in the diameter of the seminiferous tubules and in the spermatogonial population and number of spermatozoa. Spermatozoa and elongated spermatids were rare. In the group treated with sodium fluoride, focal disorganization of the seminiferous tubules associated with a marked loss of many of the germ cells and the lack of sperms were noted. Degenerated Leydig cells were observed. Sodium fluoride -treatment showed mild sloughing of germ cells from the basement membrane. Enlarged intercellular spaces between germ cells and Sertoli were observed. Morphologically, there was disruption of the seminiferous epithelium, as indicated by large intercellular spaces between Sertoli cells, and between Sertoli and germ cells (Figs. C, D)

The testis shows no histopathological changes in groups treated with sodium fluoride and inulin. The testes show normal spermatogenic cells and many sperms were noticed. Increase in the diameter of seminiferous tubules, spermatids and Leydig cells were seen. Supplemented group with inulin had well-defined seminiferous tubules lined by spermatogonia, primary and secondary spermatocytes, spermatids (in various phases of spermatogenesis) and the spermatozoa were easily identified. The interstitial cells were highly developed; being relatively large and irregular in shape (Fig. E).Control rats received distilled water showing normal seminiferous. Tubules with all stages of spermatogenesis, Normal inter-tubular Spaces with connective tissue, the lumen filled with spermatozoa.

In the current study, the testicular tissues of rats received sodium fluoride revealed degenerative changes and arrest of spermatogenesis. Also showing, decreases in the spermatogonial population and number of spermatozoa. These findings were go parallel with the results of Sun et al. (2011) who observed that fluoride exposure induced a marked change in testis structure including the disarrangement of spermatogenic cells and the reduction in luminal sperm. Further confirmation of the present results comes from the study of Pushpalatha et al. (2005) who mentioned that fluoride induces the changes in spermatogenic process.

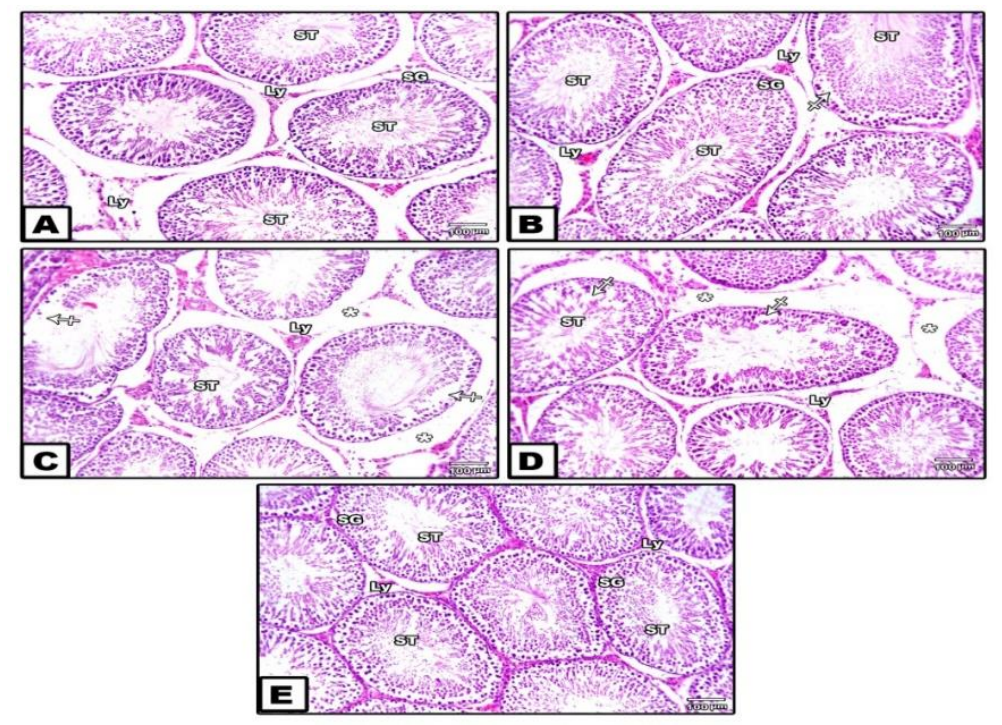

Fig.(4) :( A-E). Photomicrographs of histological sections of rat testis.

(A). Control showing normal arrangement of germ cells.

(B). Inulin supplemented group showing normal morphological appearance of seminiferous tubules with normal spermatogenic cells.

(C,D). Sodium fluoride-treatment showing massive reduction of spermatogenic, detached spermatogenic cells, lumen devoid of spermatozoa and shrinkedseminiferous tubule with incomplete spermatogenesis.

(E). sodium fluoride\& inulin

Abbreviations; ST-Seminiferous Tubules, SG-Spermatogonia, Ly- Leydig cells, Cross arrows-Sloughing of germ cells, Star-Enlarged intercellular spaces or Damage of Leydig cells.hematoxylin and eosin staining. 
Similar observations were investigated by (Guzick $\boldsymbol{e t}$ al., 2001) showing sperm with any abnormal morphology could result in the low function, adversely impacting on the successful fertilization. In addition, that $\mathrm{NaF}$ adversely affected the sperm dysfunction and sperm chromatin structure in dose dependent mice (Sun

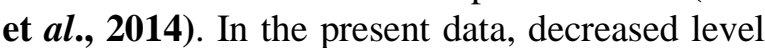
of spermatogenesis and qualitatively affected the morphological structure of the testicular tissue were observed (Dvoráková-Hortová et al., 2008).

The results reported in histopathological analysis of testis in Na-F treated males, where severe necrotic degenerative changes in seminiferous epithelium of testicular tissues, deficiency of sperms in lumina, enlarged intercellular spaces between germ cells and Sertoli, numbers of spermatid giant cells were also detected. The results are in agreement with earlier reports (Wan et al., 2006; Gupta et al., 2007; Tiwari and Pande, 2009 and El-lethey $e t$ al., 2011). Germ cells, in comparing with somatic cells, are more susceptible to oxidative germ cells are intimately associated with the free radical generating phagocytic Sertoli cells; germ cell plasma membrane contains a higher amount of polyunsaturated fatty acids that are vulnerable to oxidation by free radicals (Lenzi et al., 2000).

In the present study from histological observations of testis revealed that the number of sperms decreased, spermatogenic cells disarranged, supported previous reports. That $\mathrm{NaF}$ markedly induced histopathological lesions of testis in different degree (Gupta et al., 2007 and Han et al., 2015). In contrast, Sprando et al. (1997) reported that $\mathrm{NaF}$ treatment did not adversely affect spermatogenic activity in animals. This toxic effect of fluoride on reproduction is due to inhibition of enzyme activity; particularly of enzymes whose cofactor is the action of a bivalent metal like $\mathrm{Mg}, \mathrm{Ca}, \mathrm{Zn}$, and Se.

Analysis of testicular histology induce shriveled seminiferous tubule and the diminution of mature sperm in the lumen of the seminiferous tubule. This was in conformity with (Ghosh $\boldsymbol{e t}$ al., 2002) which elucidated that fluoride treatment was associated with a reduction in mature sperm in the lumen of the somniferous tubule. Histopathological alterations in testis of the present study manifesting principally as somniferous tubule atrophy, impaired spermatogenesis and germ cell loss. This was in conformity with (Zhang et al., 2013) who reported that mitochondrial injury and degeneration after fluoride exposure were observed.

The previous investigation indicates that sufficiently high fluoride intake through drinking water; may the fertility of male rats may be inhibited after $\mathrm{NaF}$ exposure. The secretion of $\mathrm{E}_{2}$, $\mathrm{P}, \mathrm{T}, \mathrm{LH}$ and FSH was suppressed in rats exposed to NaF. These results indicate that the reproductive function of male rats exposed to $\mathrm{NaF}$ is inhibited. The study investigated the role of Inulin in reversing sodium fluoride-induced inhibited the fertility of male rats. From the results, control and Inulin treated group drains showed high similarity in the different count and motility values of sperms.

\section{References}

Chandra, A.K., Ghosh, R., Chatterjee, A., Sarkar, M. (2007): Effects of vanadate on male rat reproductive tract histology, oxidative stress markers and androgenic enzyme activities. J. Inorganic Biochem., 101: 944-956.

Dong, C., Cao, J., Cao, C., Han, Y., Wu, S., Wang, S., Wang, J. (2016). Effects of fluoride and aluminum on expressions of StAR and P450scc of related steroidogenesis in guinea pigs'testis. Chemosphere, 147, 345-351.

Dvoráková-Hortová K, Sandera M, Jursová M, Vasinová J, Peknicová J. (2008). The influence of fluorides on mouse sperm capa citation. Anim. Reprod. Sci., 108, 157-170.

Edzwald JK (2011). Water quality and treatment: a handbook on drinking water. $6^{\text {th }}$ Ed. New York: McGraw-Hill.

Eraslan, G., Kanbur, M., Silici, S., (2007). Evaluation of proolis Effects on some Biochemical parameters in rats treated with sodium fluoride. Pesticide Biochemistry and Physiology, 88(3): 273-283.

Freni SC. (1994). Exposure to high fluoride concentrations in drinking water is associated with decreased birth rates. J Toxicol Environ Health, 42,109-121.

Ghosh, D.; Das Sarkar, S.; Maiti, R.; Jana, D.\& Das, U. (2002): Testicular toxicity in sodium fluoride treated rats: association with oxidative stress. Reprod Toxicol, 16 (4): 385-390.

Gupta R., Khan T., Agrawal D., Kachhawa J. (2007). The toxic effects of sodium fluoride on the reproductive system of male rats. Toxicol Ind Hlth, 23 (9): 507-513.

Guzick DS., Overstreet JW., Factor-Litvak P., Brazil CK., Nakajima ST., Coutifaris C., Carson SA., Cisneros P., Steinkampf MP., Hill JA., Xu D., 
Vogel DL. (2001). Sperm morphology, motility, and concentration in fertile and infertile men. $N$ Engl J Med, 345, 1388-1393. (National Cooperative Reproductive Medicine Network).

Han, H., Sun, Z., Luo, G.,Wang, C.,Wei, R.,Wang, J. (2015): Fluoride exposure changed the structure and the expressions of reproductive related genes in the hypothalamus-pituitary-testicularaxis of male mice. Chemosphere, 135, 297-303.

El-ethey H. S., Kamel M. M., Shaheed I. B. (2011). Perinatal Exposure to Sodium Fluoride with Emphasis on Territorial Aggression, Sexual Behaviour and Fertility in Male Rats, Life Science Journal, 8(2): 686- 694.

Huang, C.; Niu, R., Wang, J. (2007): Toxic effects of sodium fluoride on reproductive function in male mice. Fluoride, 40(3): 162-168.

Izquierdo-Vega, J. A.; Sánchez-Gutiérrez, M., María Del Razo, L. (2008). Decreased in vitro fertility in male rats exposed to fluoride-induced oxidative stress damage and mitochondrial trans membrane potential loss. Toxicology and Applied Pharmacology, 230, 352-357.

Kim J, Kwon WS, Rahman MS, Lee JS, Yoon SJ, Park YJ, You YA, Pang MG (2015). Effect of sodium fluoride on male mouse fertility. Andrology, 3 (3): 544-551.

Lenzi A, Gandini L, Picardo M, Tramer F, Sandri G, Panfili E. (2000). Lipoperoxidation damage of spermatozoa polyunsaturated fatty acids (PUFA): scavenger mechanisms and possible scavenger therapies. Front Biosci, 5, 1-5.

Li M., Cao J., Chen J., Song J., Zhou B., Feng C., Wang J. (2016). Waterborne fluoride exposure changed the structure and the expressions of steroidogenic-related genes in gonads of adult zebrafish (Daniorerio). Chemosphere, 145, 365375.

Long H, Jin Y, Lin M, Sun Y, Zhang L, Clinch C. (2009). Fluoride toxicity in the male reproductive system. Fluoride, 42, 260-276.

Lu Z., Wang S., Sun Z, Niu, R., Wang J. (2014). In vivo influence of Sodium fluoride on sperm chemotaxis in male mice. Arch Toxicol, 88, 533539.

Ortiz-Perez, D., Rodriguez-Martinez, M., Martinez, F., Borja-Aburto, V.H., Castelo, J.,Grimaldo, J.I., de la Cruz, E., Carrizales, L., and Diaz-Barriga, F., (2003). Fluoride-induced disruption of reproductive hormones in men. Environ. Res., 93, 20-30

Pushpalatha,T.; Srinivas, M. \& Sreenivasula Reddy,P. (2005). Exposure to high fluoride concentration in drinking water will affect Spermatogenesis and steroidogenesis in male albino rats. Bio Metals, 18 , 207-212.

Reddy, P.; Pushpalatha, T., Reddy, P. (2007):
Suppression of male reproduction in rats after exposure to sodium fluoride during early stages of development. Naturwissenschaften, 94 (7): 607611

Shoaib M., Shehzad A., Omar, M., Rakha A., Raza, H., Sharif HR., Shakeel A., Ansari A., and Niazia S. (2016). Inulin: Properties, health benefits and food applications. Carbohydrate Polymers, 147, 444-454.

Spittle B. (2009). Halting the inertia of indifference: fluoride and fertility revisited [editorial]. Fluoride 42, 159-161.

Sprando RL, Collins TF, Black TN, Rorie J, Ames MJ, et al. (1997). Testing the potential of sodium fluoride to affect spermatogenesis in the rat. Food Chem Toxicol 35, 881-890.

Sun Z., Niu R., Su K., Wang B., Wang J., Zhang J., Wang J. (2010). Effects of sodium fluoride on hyper activation and $\mathrm{Ca}^{2+}$ signaling pathway in sperm from mice: an in vivo study. Arch Toxicol 84 (5): 353-361.

Sun Z, Niu R, Wang B, Jiao Z, Wang J, Zhang J, Wang S, Wang J (2011). Fluoride-induced apoptosis and gene expression profiling in mice sperm in vivo. Arch Toxicol 85 (11):1441-1452.

Sun Z, Niu R, Wang B, Wang J (2014). Altered sperm chromatin structure in mice exposed to sodium fluoride through drinking water. Environ Toxicol 29 (6):690-696.

Sun, Z.; Zhang, W.; Xue, X.; Zhang, Y.; Niu, R.; Li, X.; Li, B.; Wang, X. \& Wang, J. (2016): Fluoride decreased the sperm ATP of mice through inhabiting mitochondrial respiration. Chemosphere, 144, 1012-1017.

Susheela, A. and Jethanandani, P. (1996): Circulating testosterone levels in skeletal fluorosis patients. $J$ Toxicol Clin Toxicol, 34 (2): 183-189.

Tiwari S, Pande R. (2009). Effect of fluoride on the hematological parameters and reproductive organs of male albino rat. J. Ecophysiol. Occup Hlth, 9, 119-129

Wan, S.; Zhang, J. \& Wang, J. (2006): Effects of high fluoride on sperm quality and testicular histology in male rats. Fluoride 39 (1): 17- 21.

Zhang, S., Jiang, C., Liu, H., Guan, Z., Zeng, Q., Zhang, C., Lei, R., Xia, T., Gao, H., Yang, L., Chen, Y., Wu, X., Zhang, X., Cui, Y., Yu, L., Wang, Z., and Wang, A. (2013). Fluoride elicited developmental testicular toxicity in rats: roles of endoplasmic reticulum stress and inflammatory response. Toxicol. Appl. Pharmacol. 271, 206-215.

Zhu JQ, Si YJ, Cheng LY, Xu BZ, Wang QW, Zhang X, Wang H, Liu ZP (2014). Sodium fluoride disrupts DNA methylation of $\mathrm{H} 19$ and Peg3 imprinted genes during the early development of mouse embryo. Arch Toxicol 88 (2): 241-248. 


\title{
الملخص العربي
}

\author{
عنوان البحث: التأثيرات البيئية لفلوريد الصوديوم على الخصوية فى ذكور الجرذان والدور الواقي \\ لمستخلص الإنيولين النير

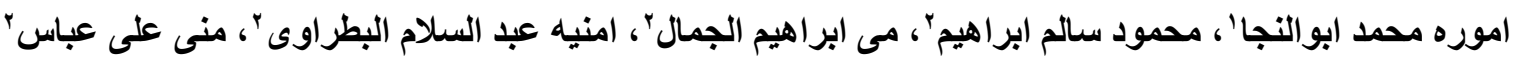 \\ ' اقسم علوم الحيوان، كلية العلوم جامعة المنصورة

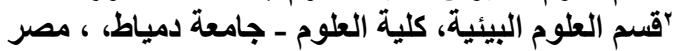

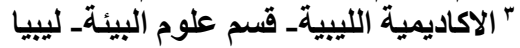

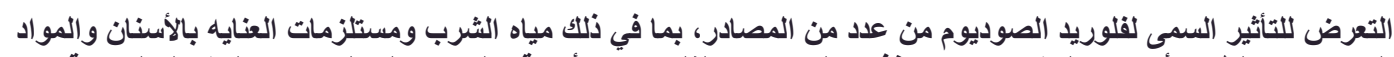

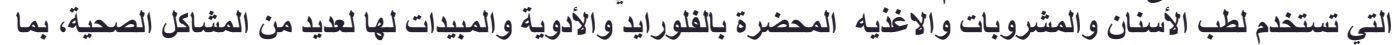

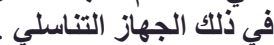

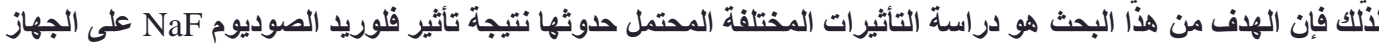

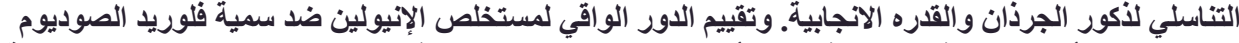

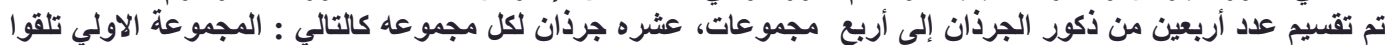

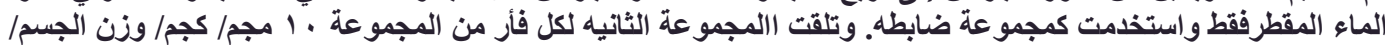

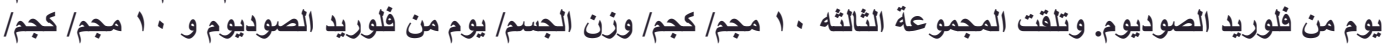

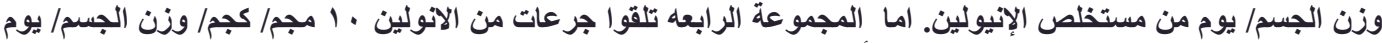

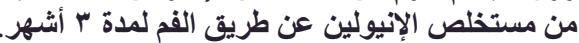

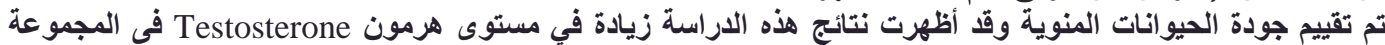

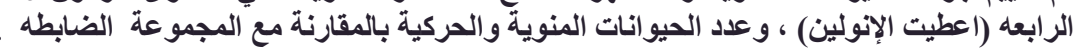

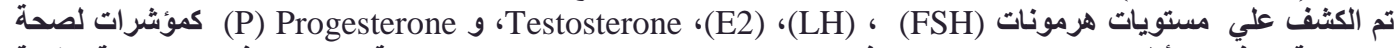

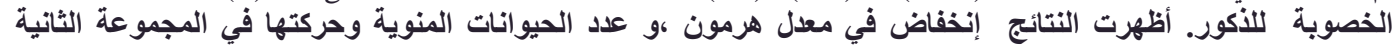

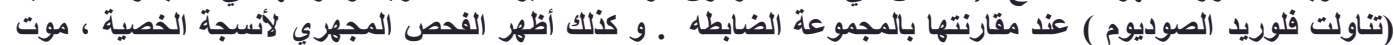

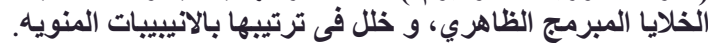

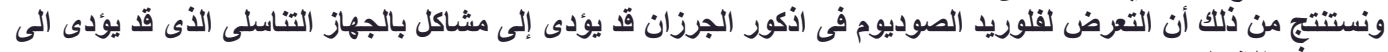

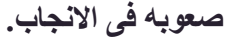

